\begin{tabular}{|c|c|c|c|c|c|c|c|c|}
\hline \multicolumn{3}{|c|}{$\begin{array}{l}\text { 2. To: (Receiving Organization) } \\
\text { Distribution }\end{array}$} & \multicolumn{2}{|c|}{ 3. From: (Originating Organization) } & \multicolumn{4}{|c|}{$\begin{array}{r}4 . \text { Related EDT No.: } \\
\text { N/A }\end{array}$} \\
\hline \multicolumn{3}{|c|}{ 5. Proj./Prog./Dept./Div.: } & \multicolumn{2}{|c|}{$\begin{array}{l}\text { 6. Design Authority/ Design Agent/Cog. } \\
\text { Engr.: }\end{array}$} & \multicolumn{4}{|c|}{ 7. Purchase Order No.: } \\
\hline \multicolumn{5}{|c|}{ 8. Originator Remarks: } & \multicolumn{4}{|c|}{$\begin{array}{l}\text { 9. Equip./Component No.: } \\
\text { N/A }\end{array}$} \\
\hline \multicolumn{5}{|c|}{ N/A } & \multicolumn{4}{|c|}{$\begin{array}{l}\text { 10. System/Bldg./Facility: } \\
\text { Spent Nuclear Facility }\end{array}$} \\
\hline \multirow{3}{*}{\multicolumn{5}{|c|}{ 11A. Design Baseline Document? [] Yes [X] No }} & \multicolumn{4}{|c|}{$\begin{array}{l}\text { 12. Major Assm. Dwg. No.: } \\
\text { N/A }\end{array}$} \\
\hline & & & & & \multicolumn{4}{|c|}{$\begin{array}{l}\text { 13. Permit/Permit Application No: } \\
\text { N/A }\end{array}$} \\
\hline & & & & & \multicolumn{4}{|c|}{$\begin{array}{l}\text { 14. Required Response Date: } \\
\text { N/A }\end{array}$} \\
\hline 15. & & DATA & RANSM & ED & (F) & (G) & (H) & (I) \\
\hline $\begin{array}{l}\text { (A) } \\
\text { Item } \\
\text { No. }\end{array}$ & (B) Documen//Drawing No. & $\begin{array}{l}\text { (C) } \\
\text { Sheet } \\
\text { No. }\end{array}$ & $\begin{array}{l}\text { (D) } \\
\text { Rev. } \\
\text { No. }\end{array}$ & $\begin{array}{l}\text { (E) Titte or Description of Data } \\
\text { Transmitted }\end{array}$ & $\begin{array}{l}\text { Approval } \\
\text { Desig- } \\
\text { nator }\end{array}$ & $\begin{array}{l}\text { Reason } \\
\text { for } \\
\text { Trans- } \\
\text { mittal }\end{array}$ & $\begin{array}{l}\text { Origi- } \\
\text { nator } \\
\text { Dispo- } \\
\text { sition }\end{array}$ & $\begin{array}{l}\text { Receiv- } \\
\text { er } \\
\text { Dispo- } \\
\text { sition }\end{array}$ \\
\hline 1 & SNF-3881 & & 0 & $\begin{array}{l}\text { Ashcroft Temperature Switch for Bay } \\
\text { Temperature }\end{array}$ & $Q$ & 2 & 1 & N/A \\
\hline & & & & & & & & \\
\hline & & & & & & & & \\
\hline & & & & & & & & \\
\hline & & & & & & & & \\
\hline
\end{tabular}

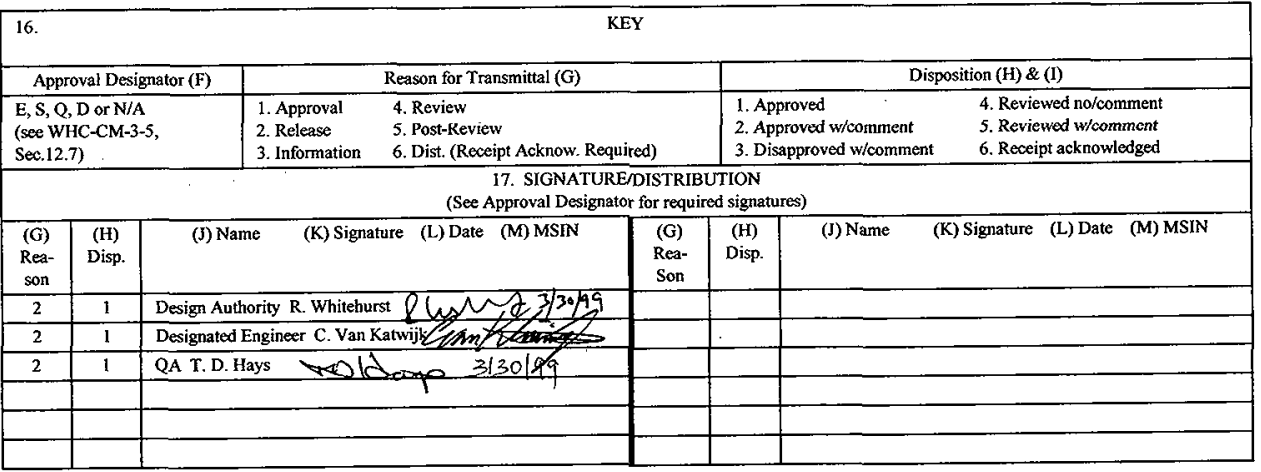

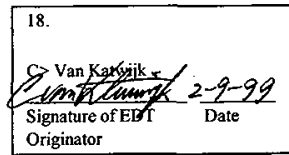

20 .
E) Title or Description of Date Transmitted 


\section{Ashcroft Temperature Switch for Bay Temperature}

Carl Van Katwijk

Numatec Hanford Co, Richland, WA 99352

U.S. Department of Energy Contract DE-AC06-96RL13200

EDT/ECN: 626255

UC: 620

Org Code: $2 \mathrm{G} 300$

Charge Code: $105559 / \mathrm{A000}$

B\&R Code: $39 \mathrm{EW} 40400$

Total Pages: 13

Key Words: Temperature Switch

Abstract: Ashcroft Temperature Switch for Bay Temperature

CGI-SNF-D-93-2-P4-006

TRADEMARK DISCLAIMER. Reference herein to any specific commercial product, process, or service by trade name, trademark, manufacturer, or otherwise, does not necessarily constitute or imply its endorsement, recommendation, or favoring by the United States Government or any agency thereof or its contractors or subcontractors.

Printed in the United States of America. To obtain copics of this document, contact: Document Control Services, P.O. Box 950, Mailstop H6-08, Richland WA 99352, Phone (509) 372-2420; Fax (509) 376-4989.

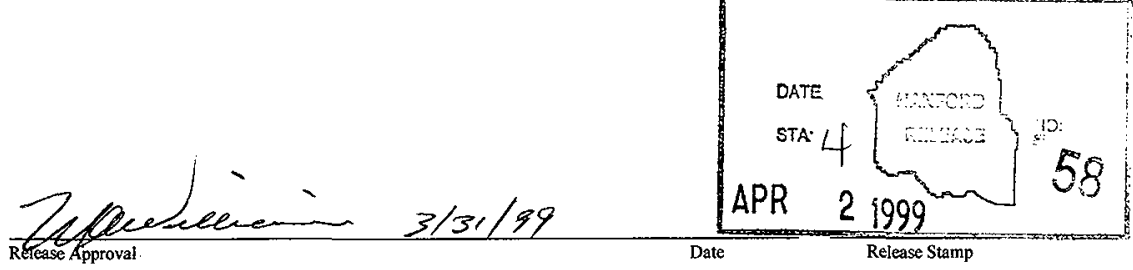

\section{Approved for Public Release}




\begin{tabular}{|c|c|c|c|}
\hline Item No.: NA & \multicolumn{2}{|l|}{ Manufacturer: } & Supplier: \\
\hline \multicolumn{2}{|l|}{ Mfg. Part/Model No.: } & \multicolumn{2}{|l|}{ Supplier's P/N: } \\
\hline \multicolumn{4}{|l|}{ Part Description: } \\
\hline \multicolumn{4}{|l|}{ End Use Description: } \\
\hline \multicolumn{4}{|c|}{ 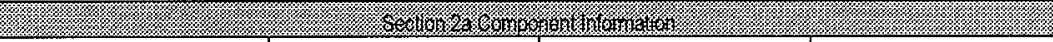 } \\
\hline $\begin{array}{l}\text { Equipment No.: SCIC-TSH } \\
\text { 1*38; TSHH 1*38; } \\
\text { TSH 1*39; TSHH1*39 }\end{array}$ & $\begin{array}{l}\text { Specification No.: W-441- } \\
\text { P4, Rev. } 2\end{array}$ & Manufacturer. Ashcroft & Past P.O. No.: NA \\
\hline $\begin{array}{l}\text { Manufacturer's Part/ Model } \\
\text { No.: Switch;-LTD-N4- } \\
\text { KK-00-027-20-95 C. }\end{array}$ & \multicolumn{2}{|c|}{ Equipment Supplier (if dfferent from manufacturer): TBD } & $\begin{array}{l}\text { Equip. Supplier's Part No: } \\
\text { NA }\end{array}$ \\
\hline \multicolumn{4}{|c|}{$\begin{array}{l}\text { Component Description: Temperature Switch, Bay Environment High-High - Provides High-High } \\
\text { Temperature Alarms to SDIC. }\end{array}$} \\
\hline \multicolumn{4}{|c|}{ 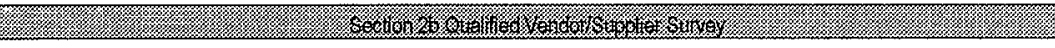 } \\
\hline \multicolumn{4}{|c|}{$\begin{array}{l}\text { 1. Is the ltem available from a catalog from a qualified NQA1 } \\
\text { Engineer or BTR)? } \\
\text { [ ] YES (go to } \# 2 \text { below) } \\
\text { [X] NO (go to procedure step 5.3.2, proceed to dedicate item.) }\end{array}$} \\
\hline \multicolumn{4}{|c|}{ 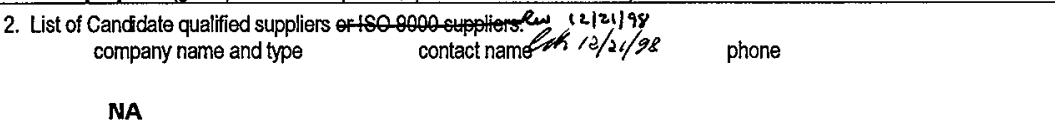 } \\
\hline \multicolumn{4}{|c|}{$\begin{array}{l}\text { 3. Recommended Procurement Strategy (coordinate with project CGI interface Engineer or BTR): } \\
\text { NA }\end{array}$} \\
\hline \multicolumn{4}{|c|}{ r. } \\
\hline \multicolumn{4}{|c|}{$\begin{array}{l}\text { 1. Question \#1: is the ltem subject to design or specification requirements that are unique to nuclear facilities or activities? } \\
\text { [ ] YES (the item is not commercial grade) } \\
{[\mathrm{X}] \text { NO (continue) }}\end{array}$} \\
\hline $\begin{array}{l}\text { 2. Question \#2: Is the Item u } \\
\text { [ ] NO (the item is no } \\
\text { [X] YES (continue) }\end{array}$ & $\begin{array}{l}\text { commercial grade) } \\
\text { complications other than nu }\end{array}$ & clear facilities or activities? & \\
\hline
\end{tabular}


3. Question \#3: Is the Item ordered from manufacturer/supplier on the basis or specifications set forth in the manufacturers catalog?

[ ] NO (the item is not commercial grade)

[X] YES (continue)

[X] All three criteria have been satisfied. The Item meets the definition of commercial grade.

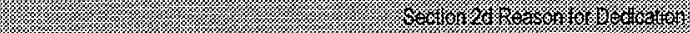

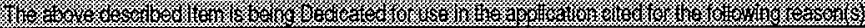

[X] Item is being purchased from a non ESL manufacturer supplier as commercial grade to be used in a Safety Class application.

[ ] liem is being purchased from a non ESL. manufacturer supplier as commercial grade to be used in a Safety Significant application.

[ I Item was purchased from a non ESL manufacturer supplier as commercial grade to be used in a Safety Class application.

[ I Item was purchased from a non ESL manufacturer supplier as commercial grade to be used in a Safety Significant application.

1 1 Other ("like-for-like', similar, substitution, replacement evaluation)

A. Part/Component Safety Function:

1. Provide Bay Environment High-High Temperature Alarm and Signal to SCIC.

(TSH 1*38 and TSH 1*39 High Temperature Contact Function is Not Used).

2.

3.

B. Part/Component Functional Mode:

Safety Function \#1:

[X] Active-Mechanical or Electrical change of state is required to occur for the component to perform its safety function.

[ ] Passive - Change of state is not required for the component to perform its safety function

Safety Function \#2:

[ ] Active - Mechanical or Electrical change of state is required to occur for the component to perform its safety function.

l 1 Passive - Change of state is not required for the component to perform its safety function Safety Function \#3:

[ ] Active - Mechanical or Electrical change of state is required to occur for the component to perform its safety function.

1 Passive - Change of state is not required for the component to perform its safety function.

C. Host Component Safety Function (if applicable):

1. NA

2.

3. 
D. Failure Mechanisms(s) and the effects on component or system safety function (see worksheet 1):

1. Failure in switch mechanism (failure of contacts to make or break) resulting in loss of temperature alarm and signal to SCIC.

2. Failure to ground resulting in loss of output signal or loss of input power resulting in loss of input signal to the SCIC.

$$
3 .
$$

4.

5.

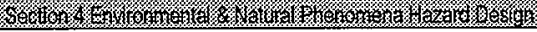

Environmental Qualification Required:

If yes: Environmental Qualification Requirements

Yes [ ]

Limiting Environmental Conditions:

No $[\mathbf{X}]$

Required Safety Functions:

Environmental Condition B

Qualification Period:

Natural Phenomena Hazard (NPH) Design Required:

If yes: NPH Design Requirements

Yes [ ]

Performance Category: PC-1

No $[\mathbf{X}]$

NPH Design Req'ts.:

Required Safety Functions: Provide High-High Temperature Alarm to SCIC

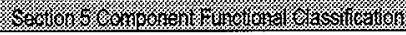

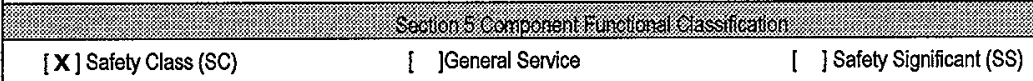

If part/component classification is dfferent from host component/system, document basis.

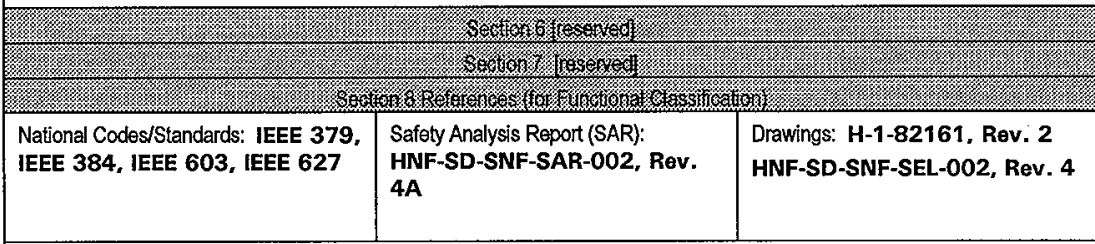

Vendor Manuals/Manufacturer/Supplier Information: Ashcroft L Series Temperature Switches, Bulletin SW-12 Other. 
Commercial Grade Item Upgrade Dedication Form

ECN No. NA

CGI No. CGI-SNE-D-93-2-P4-006

Rev. No. 0

Page 4 of 12

SNF-3881

Title: ASHCROFT TEMPERATURE SWITCH FOR BAY TEMPERATURE

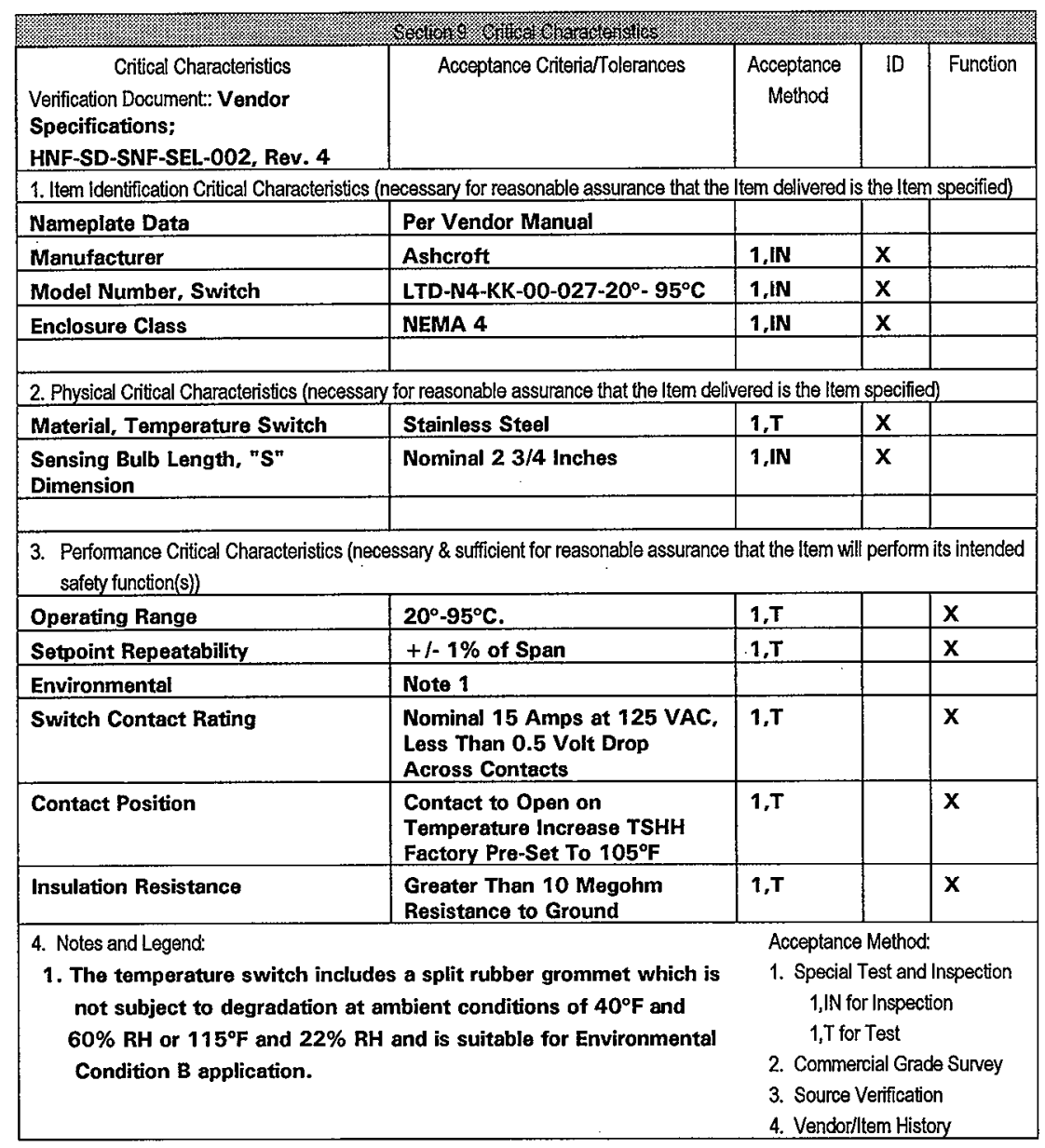




\section{Approvals:}

Designated Engineer: Pen then $12 / 26 / 98$

Design Authority. Rumand whikevest $12 / 21 / 98$

QA Engineer. ad Dlaylas 
Commercial Grade Item Upgrade Dedication Form

ECN No. NA CGINo. CGI-SNF-D-93-2-P4-006
Title: ASHCROFT TEMPERATURE SWITCH FOR BAY TEMPERATURE

Rev. No. 0

Page 6 of 12

SNF-3881

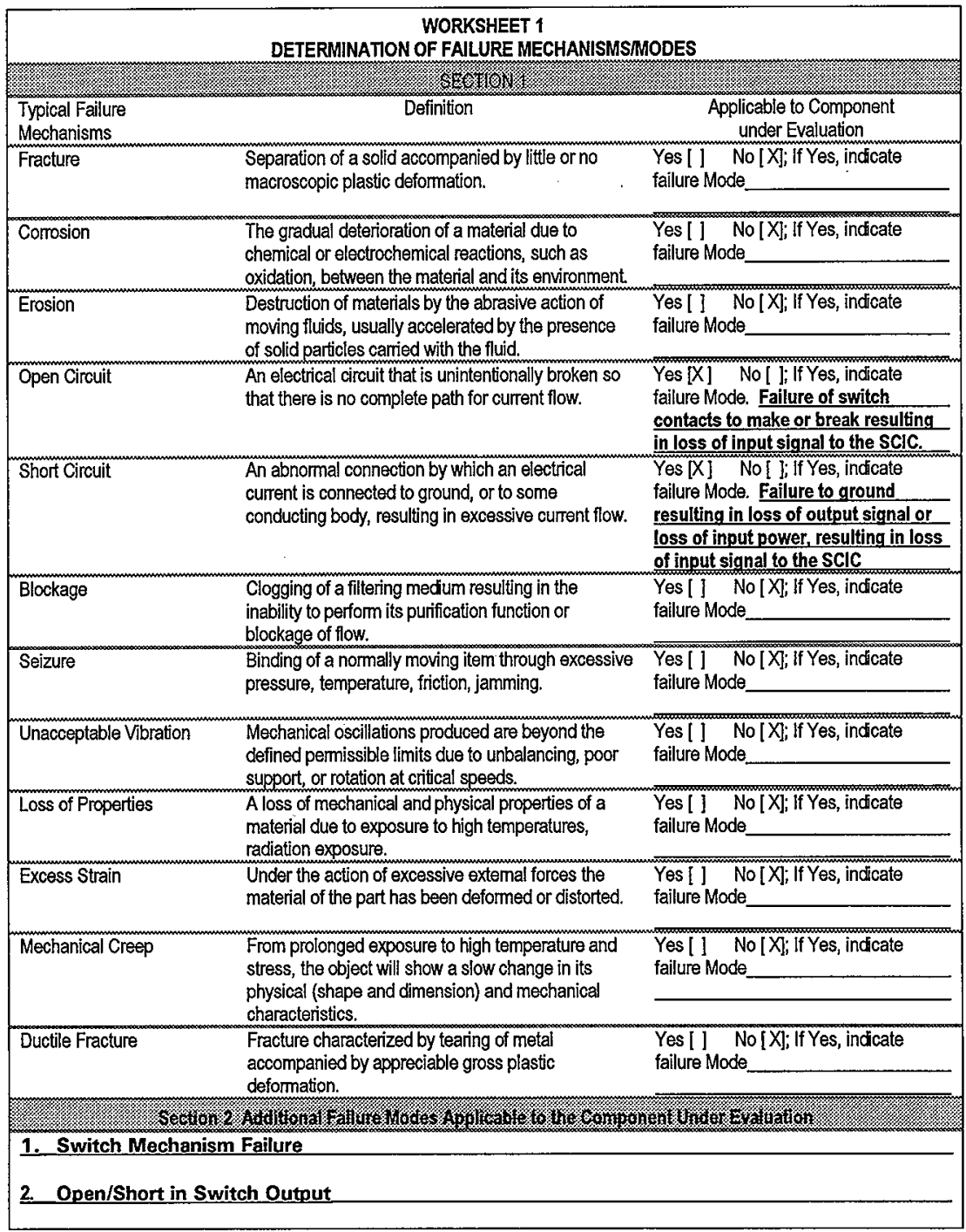




\section{CHECKLIST 1}

ACCEPTANCE METHOD 1

SPECIAL TEST/INSPECTION VERIFICATION

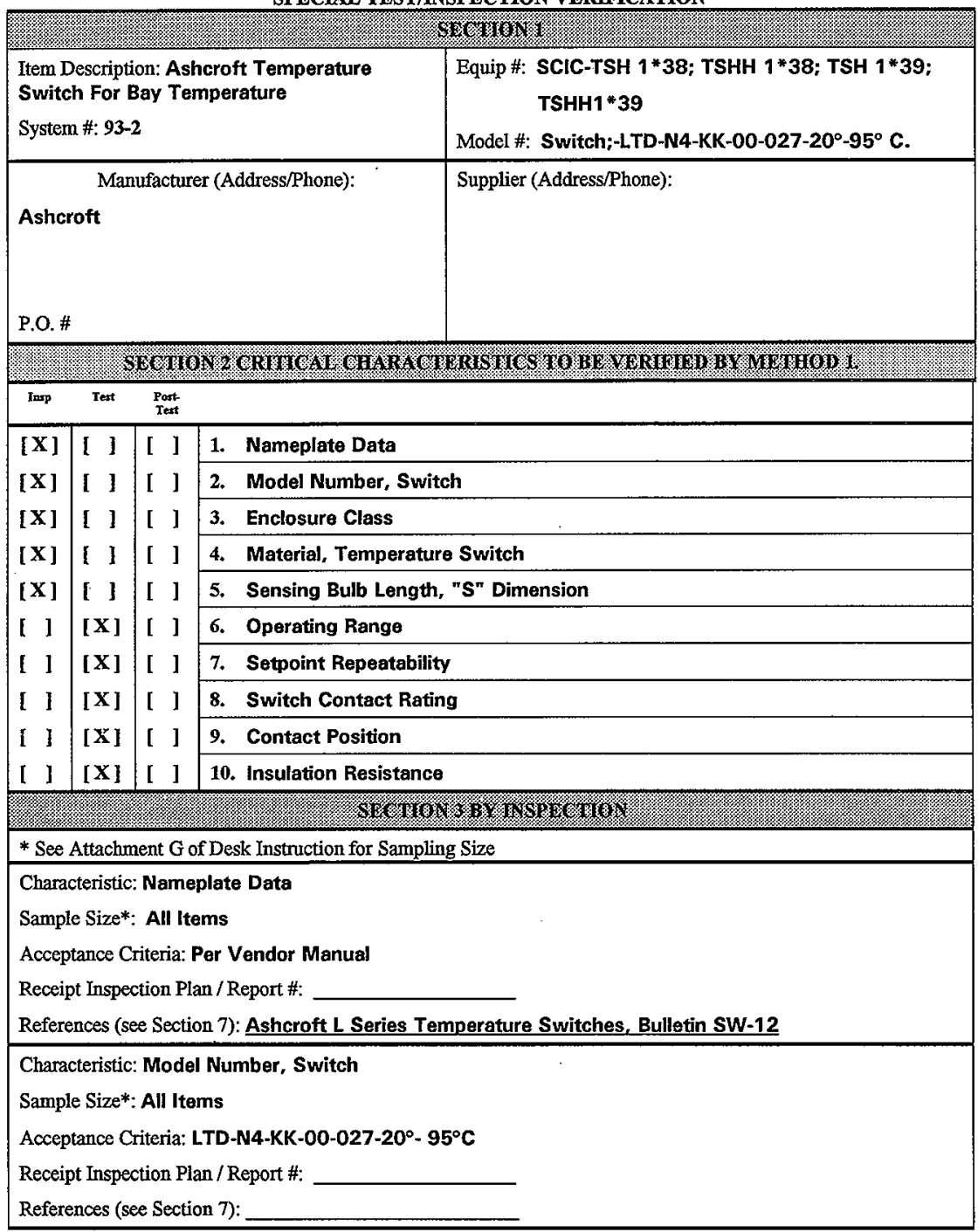




\section{Characteristic: Enclosure Class \\ Sample Size*: All ltems \\ Acceptance Criteria: NEMA 4 \\ Receipt Inspection Plan / Report \#: \\ References (see Section 7):}

Characteristic: Material, Temperature Switch

Sample Size*: All Items

Acceptance Criteria: Stainless Steel

Receipt Inspection Plan / Report \#:

References (see Section 7):

Characteristic: Sensing Bulb Length, "S" Dimension

Sample Size*: All Items

Acceptance Criteria: Nominal 2 3/4 Inches

Receipt Inspection Plan / Report \#:

References (see Section 7):

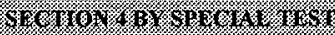

* See Attachment G of Desk Instruction for Sampling Size

Test To Be Performed by:

Number of Items to be Tested:

[ ] Purchaser

[ ] Supplier/Manufacturer**

Test/Inspection Location:

[ ] Other

Characteristic for Test: Operating Range

Acceptance Criteria: $20^{\circ}-95^{\circ} \mathrm{C}$

Sample Size*: Normal Sampling Size

Actual Test Value:

Test Plan and Report \#: References (see Section 7):

Characteristic for Test: Setpoint Repeatability

Acceptance Criteria: $+/-1 \%$ of Span

Sample Size*: Normal Sampling Size

Actual Test Value:

Test Plan and Report \#: References (see Section 7):

\section{Characteristic for Test: Switch Contact Rating}

Acceptance Criteria: Nominal 15 Amps at 125 VAC, Less Than 0.5 Volt Drop Across Contacts

Sample Size*: Normal Sampling Size

Actual Test Value:

Test Plan and Report \#: References (see Section 7): 
Characteristic for Test: Insulation Resistance

Acceptance Criteria: Greater Than 10 Megohm Resistance to Ground

Sample Size*: Normal Sampling Size

Actual Test Value:

Test Plan and Report \#:

References (see Section 7):

Characteristic for Test: Contact Position

Acceptance Criteria: Contact to Open on Temperature Increase. TSHH Factory Pre-Set to $105^{\circ} \mathrm{F}$

Sample Size*: Normal Sampling Size

Actual Test Value:

Test Plan and Report \#: References (see Section 7):

**If Supplier/Manufacturer or Other, Refer to CGI Checklist-2 for Support Information 


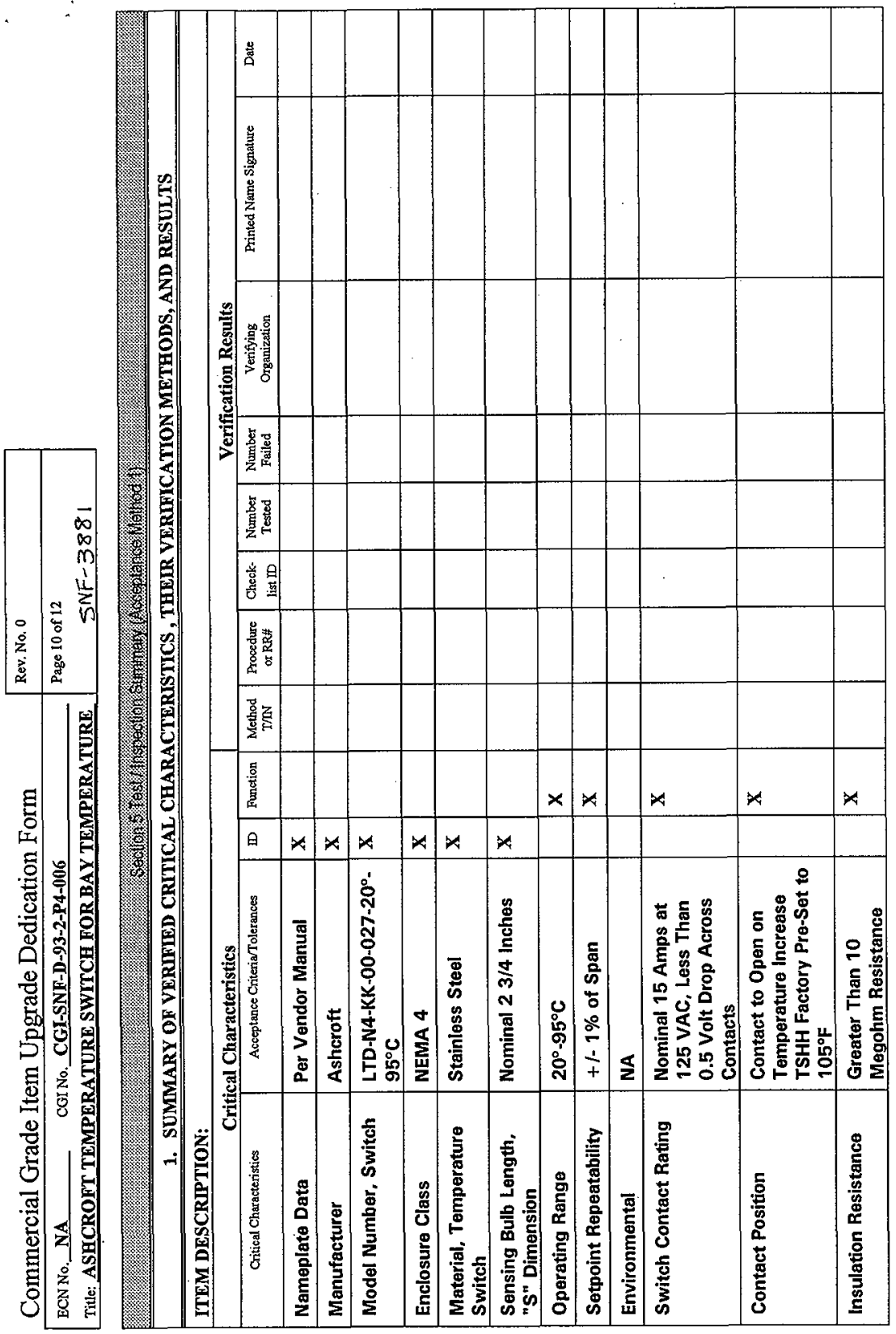




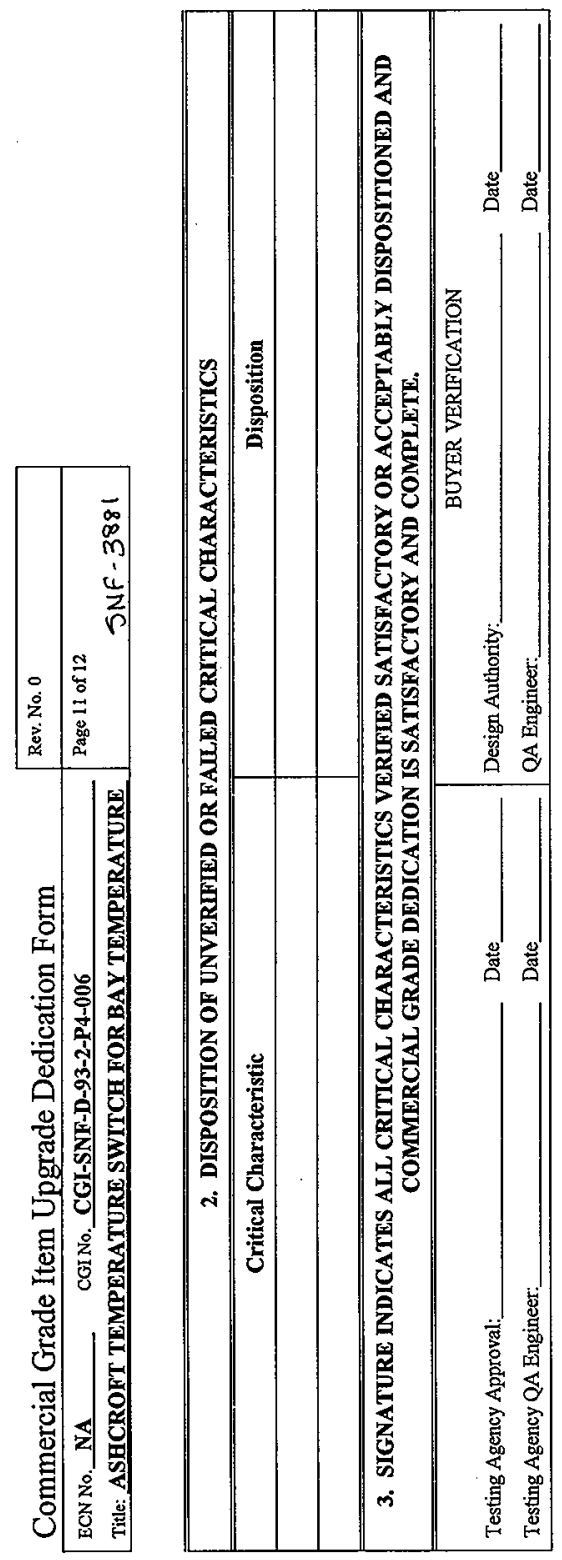

$\stackrel{\infty}{\stackrel{̊}{\jmath}}$

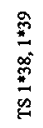


Commercial Grade Item Upgrade Dedication Form ECN No. NA CGI No. CGI-SNF-D-93-2-P4-006

Tite: ASHCROFT TEMPERATURE SWITCH FOR BAY TEMPERATURE

\begin{tabular}{|c|c|}
\hline \multicolumn{2}{|l|}{ Name } \\
\hline Design Authority & () \\
\hline $\mathrm{QA}$ & () \\
\hline QC & () \\
\hline Cog - Engineer & () \\
\hline CGI Engineer & $(\quad)$ \\
\hline Procurement Engineer & ( ) \\
\hline \multirow{2}{*}{\multicolumn{2}{|c|}{ 1) $(1)$}} \\
\hline & \\
\hline \multicolumn{2}{|l|}{ Initial Procurement Documents } \\
\hline \multicolumn{2}{|l|}{ [ ] Drawings: } \\
\hline \multicolumn{2}{|l|}{ I I Manuals (specify type \& number): } \\
\hline \multicolumn{2}{|l|}{ [ ] Design Calculations } \\
\hline \multicolumn{2}{|l|}{ I I Installation Instructions } \\
\hline \multicolumn{2}{|l|}{ I ] Operation Instructions } \\
\hline \multicolumn{2}{|l|}{ [ ] Calibration Instructions } \\
\hline \multicolumn{2}{|l|}{ I I Manufacturer's Recommended Spare Parts List } \\
\hline \multicolumn{2}{|l|}{ I I Other: } \\
\hline \multicolumn{2}{|l|}{ Procurement Documents } \\
\hline \multicolumn{2}{|l|}{ I I Certificate of Conformance/Compliance } \\
\hline \multicolumn{2}{|l|}{ [ ] Seismic Qualification Certificate } \\
\hline \multicolumn{2}{|l|}{ [ ] Environmental Qualification Certificate } \\
\hline \multicolumn{2}{|l|}{ [ ] Test Report (s): } \\
\hline \multicolumn{2}{|l|}{ I I Inspection Report (s): } \\
\hline \multicolumn{2}{|l|}{ [ ] CMTRs for ASME Pressure Retaining Materials } \\
\hline \multicolumn{2}{|l|}{ I I Valve Seat Leakage Report } \\
\hline \multicolumn{2}{|l|}{ [ ] Weld Records } \\
\hline \multicolumn{2}{|l|}{ [ ] Material Traceability Record } \\
\hline I I Other: & \\
\hline
\end{tabular}

